\title{
Measurement of brand equity at the facility level in accommodation sector and an application
}

\author{
Duriye Bozok ${ }^{1}$, Kudret Gul $^{2}$, Melike Gul ${ }^{3}$, Gencay Saatci ${ }^{4}$ \\ ${ }^{1}$ Gastronomy and Cousin Art Deparment Tourism Faculty Balikesir University, Balikesir, Turkey \\ ${ }^{2}$ Tourism and Hotel Management Department Balikesir Vocational School Balıkesir University, Balikesir, Turkey \\ ${ }^{3}$ Tourism and Hotel Management Department Sindirgi Vocational School Balıkesir University, Balikesir, Turkey \\ ${ }^{4}$ Tourism and Hotel Management Department Harmancik Vocational School Uludag University, Bursa, Turkey
}

\section{Email address:}

dbozok@balikesir.edu.tr (D. Bozok) kgul@balikesir.edu.tr (K. Gul) melikegul@mynet.com (M. Gul) gencaysaatci@uludag.edu.tr (G. Saatci)

\section{To cite this article:}

Duriye Bozok, Kudret Gul, Melike Gul, Gencay Saatci. Measurement of Brand Equity at the Facility Level in Accommodation Sector and an Application. Science Journal of Business and Management. Vol. 3, No. 1, 2015, pp. 1-10. doi: 10.11648/j.sjbm.20150301.11

\begin{abstract}
Today, the intense competition in the tourism market, rapid development of information and communication technologies, increase of the customer knowledge and experience have increased the need for product differentiation. This situation has led to more emphasis to brands. Intangibility of touristic products is exacerbated by the need for labeling and branding can be used as an effective marketing tool in the sector. A good brand adds value to the tourism product and it is more effective in the selection of accommodation of customers. Therefore, to determine tourists' perception of brand equity is very important. In the literature, the components used in the measurement of brand equity can be listed as brand awareness, perceived quality, brand associations and brand loyalty. In our study, the effect of the brand components on the choice of the accommodations will be determined. For this purpose, customers' perception of the brand equity which is effected in choosing a hotel will be measured in an accommodation facility in the city centre of Bursa in Turkey.
\end{abstract}

Keywords: Accommodation Facility, Facility Branding, Brand Equity, Brand Component

\section{Introduction}

Today, increasing competition among enterprises, the rapid developments in information and communication technology force firms to be more consumer-oriented (Taskin and Akat, 2012:1). Expansion of competition has also increased the need for differentiated products. That need has led to the use of the brand and new concepts associated with the brand in the literature (Aysen, Yayli and Helvaci, 2012:182).

There is no possibility of pre-tested of services before using them in the tourism sector. Thus, in order to give confidence to the customers, branding is even more important (Selvi and Temeloglu, 2008:100). Tourist products are often intangible. Therefore, one of the best marketing tools of these products is the brand (Pekyaman, 2008:111). On the other hand, in determining marketing effectiveness of an accommodation facilities operating in the tourism sector, it is vital to measure customer perception of the value for this property. Measuring brand equity of a tourist facility is also important for analyzing the life cycle (Kocaman and Gungor, 2012:143).
In recent years, many concepts have emerged about branding in the literature. "Consumer-based brand equity" concept is one of them. All brand value definitions are based on two main perspectives. The first one emphasizes the value of company that is called the "financial perspective" and the second one is "marketing perspective" which is based on brand equity in the eyes of the consumers. Consumer-based brand equity was examined in this study.

Brand equity dimensions depending on multidimensional analysis indicating the effectiveness of each dimension on brand equity and relationship among each one was also examined in this study. A visionary approach is also applied for indicating which services are effective on customer's perception regarding brand equity that is rarely mentioned in the literature. Survey has been applied on tourists staying at a five-star hotel operating in the city centre of Bursa in Turkey.

\subsection{Branding in the Hospitality Industry}

Today, branding is becoming increasingly important in the service sector as in the industrial market (Y1lmaz and Ercis, 2012:29). With strong brands, customers are able to reify 
intangible product easily and the concept of branding becomes more important in the service sector (Taskin and Akat, 2012:141). Consumers perceive industrial products as brand. However, consumers perceive service business as the brand. Because the services offered by the company is used in service business.

Branding is an effort to create an identity about tourist products in the perceptions of consumers in the tourism industry (Ozkul and Demirer, 2012:159). Brand is just a matter of promise. The tourism business itself is the ability to make a promise and fulfill it. Therefore tourist product itself is very convenient for branding (Doganli, 2006:71).

In Turkey, No. 556 on the Protection of Trademarks in accordance with Article 5 of the Decree-Law, brand of an enterprise include every signs to distinguish it's goods or services from another goods or services, involving provided names, especially the words, shapes, letters, numbers, goods format or packaging etc. with drawings that can be viewed or in a similar manner can be expressed by means of media that can be transmitted and can be replicated (http://www.turkpatent.gov.tr).

Brand is not only expressed as the name, logo or symbol, it also covers company's entire value of the tangible and intangible (Toksari, 2010:1). According to Murphy (1990:25) brand consists not only from a physical product, it consists also from certain privileges. He emphasizes that the brand can also be created without name, sign, symbol or logo. Becoming the brand name of a Chinese restaurant is an example of this issue (Jones and Bonevac, 2013: 115). In the same way, perceiving an accommodation facility as a separate brand by consumers is a key for success in the hospitality sector.

Nowadays tourism businesses are aware of creating a successful brand to survive in the highly competitive market and they realize that they have to ensure the continuity of this brand. Therefore, accommodation's managers have begun to pay more attention for branding efforts (Karacan, 2006:5). Gunes (2011:46) also indicates that success in the tourism sector depends on a good interpretation of the changing trends and appropriate services related to tourist demand.

In general, the quality of a particular service is associated with a particular brand name. So people are confident that brand offers the same quality or service wherever they are sold (Cabar, 2010:56). Branding in the hospitality industry is a definition of accommodation facility in the minds of the people (Yavuz, 2007:45). In this way, it is possible to prefer an accommodation facility again (Doganli, 2006:83).

Branding a tourist product, creating brand equity and gaining an identity implies one step ahead in the competition (Ilban, 2008:122). For this reason, creating a brand depends on the premise of the brand conditions that are quality, service and innovation (Ertugrul and Demirkol, 2007:68). In fact, businesses can gain competitive advantage through successful brands (Lassar, Mittal and Sharma, 1995: 11).

\subsection{Brand Equity in the Hospitality Industry}

Brand alone is not sufficient for a product or service in today's competitive environment. A brand is significant only when it has value in the minds of consumers. Therefore, value measurement is an important step in the branding process (Aktepe ve Sahbaz, 2010: 69). The main reason of becoming more important of brand value is the success of business which has higher brand values and ranking business with brand values (Ozguven, 2010:141).

Christopher (1996:56) defines brand value as all of the hallmarks providing specific values to the consumer. Kamakura and Russell (1993), Park and Srinivasan (1994), Rangaswany, Burke and Olivia (1993) also defined brand value as a value that added a product or service by its name. Accordingly, a brand value can be estimated by subtracting the benefits of the physical characteristics of a product or service from the overall benefits of a brand (Yoo and Donthu, 2000:195). Kamakura and Russell (1993) defined brand value as the output of long-term investments that designed to configure different advantages of a product or service when compared with competitors. According to Ailawadi, Lehmann ve Neslin (2003) brand value is the outputs or market effects that obtained with the trademark of a product brand. Moisescu (2005:213) also stated that brand value is sources and all sufficiency that provided by the business's products or services to customers, and added to the brand's name or symbol.

Brand value concept is examined as financial-based and market-based with two dimensions in the literature. The researchers supporting financial dimension, declared brand value as cash flow which is created by the brand name of a product (Kocaman and Gungor, 2012:145).

Brand equity concept is also used as the mean of "the brand's perceptual value" in the literature. In other words, this concept can be defined as "consumer-based brand equity". According to Virvilaite and Jucaityte (2008: 112) consumer-based brand valuation methods are the psychological and behaviour-oriented brand valuation methods. Two most accepted models on this subject in the literature are the Aaker's Consumer-Based Brand Equity Model and the Keller's Consumer-Based Brand Equity Pyramid Model (Kocaman ve Güngör, 2012: 146; Christodoulides and Chernatony, 2009: 7).The study is based on especially these two models.

\subsection{Brand Equity Dimensions of an Accomadation Facility}

Aaker (1991) stated consumer based brand equity as the total of brand awareness, brand associations, perceived quality and brand loyalty and the value attributed to these brands by consumers. Therefore, his brand value model builds on five main dimensions. These are brand awareness, brand associations, perceived quality, brand loyalty and the other assets belongs to brand. The other assets belong to brand that has been identified as the fifth dimension; patents, the company's distribution channels and issues not directly related with consumer. It is stated that the first four dimensions should be used for brand equity analysis (Toksari, 2010:66).

Keller (2001:15) asserted four-dimensional pyramid for consumer based brand equity. The dimensions of this 
pyramid are as follows:

- Brand Identity (Brand Awareness)

- Brand Meaning (Brand Associations)

- Brand Response (Reactions, Perceptions)

- Brand Relations (Brand Loyalty).

As seen above, Keller's brand value pyramid and Aaker brand value dimension match exactly. In this study, these four main dimensions (brand awareness, perceived quality, brand association, brand loyalty) are examined.

\subsection{Brand Awareness}

The most important indicator of a brand's presence in the minds of consumers is brand awareness which can be defined as a person's active or passive information about a particular brand (Selvi and Temeloglu, 2008:96). According to Erdil and Uzun (2010:221), brand awareness is the ability of a potential tourist to recognize or recall an accommodation establishment.

Brand awareness can be expressed as brand consciousness (Aaker, 2013: 24; Toksari ve Inal, 2011: 75; Taskin ve Akat, 2010: 4). According to Aaker (1990), a brand is in the minds of consumer as a result of comparing with competing brands. In addition, it is emphasized that consumer-based brand equity can arise in the case of high degree of brand awareness with strong, favorable and unique brand perception (Kakati and Choudhury, 2013: 26).

The recognition and recall are two important aspects of brand awareness. Recognition of a brand would be concerned if previously heard by customers. But recall of a brand occurs when a trademark is used by customers (Shabbir and Rehman, 2013:349). For example, if we ask a group of people which hotel brand name come to their mind first, they possibly tell Hilton, Sheraton etc. They never say X hotel that ever widely unheard. But if we give them a list of hotel accommodations, they would be aware of $\mathrm{X}$ hotel. But this hotel will not make any sense in these people's minds, if they never stay at X hotel or a very closer person tell them about this hotel. In other words, X hotel is not familiar to this group of people.

It is impossible to create brand awareness, if target customers do not have much time to hear and understand the information about the brand (Godin, 2013:23). Therefore, the first step for creating a brand is to understand the needs of the market and identifying the brand. For this purpose, the development of a brand strategy and analyzing target market is important (Trimeche and Wakabayashi, 2012: 27-28).

Given the competitive conditions in the market, it is more difficult to create awareness on consumer preferences (Cako and Cinar, 2012:37). In addition, intangibility and the absence of pre-tested possibility of hotel's product makes more important to create brand awareness in the hospitality industry (Pekyaman, 2008:111; Selvi and Temeloglu, 2008:100).

\subsection{Perceived Quality}

Perceived brand quality is one of the most important dimensions of brand equity. It contains intangible and general feelings about accommodation facility as well as reflecting the property's characteristics (Aaker, 2007:107; Gil et al., 2007:189). The brand quality is associated with products features such as reliability and performance. The concept is defined as perception resulting from subjective evaluations of tourists. In other words, the perceived quality is not the actual quality of accommodation facility. It is the judgment that is made about service performance of the facility by consumer after using and assessing it (Ipar, 2010:98).

Vazquez et al. (2002:28) evaluate perceived quality as consumers feel about the brand. Tourists evaluate an accommodation facility how they feel and perceive its quality. According to Erisen (2010:26), increasing tourist satisfaction regarding an accommodation facility increases the value of this accommodation.

Shabbir and Rehman (2013:354) indicate positive relationship between perceived quality and brand equity. They also emphasize that perceived quality are the most important factors in creating a strong brand equity. In the same way, Netemeyer et al. (2004:210) indicate that the perceived quality determines purchase intent of customers. Thus, perceived quality is of great importance to create brand equity for an accommodation facility.

\subsection{Brand Associations}

Aaker expressed brand associations as everything that is formed in the minds of consumers about the brand (Erdil ve Basarir, 2009: 219; Marangoz, 2007: 463). On the other hand, Keller (1998:93) grouped brand associations under three main categories as attributes, benefits, and attitudes. The attributes of a brand express qualities related and non-related with accommodation facility (Yener, 2013:90). The brand's benefits express functional, experiential and symbolic benefits of brand (Toksari, 2010: 83). The most intangible and the highest levels of brand associations are the attitudes. The concept represents the overall assessment of an accommodation facility by tourists (Keller, 1998: 101).

Brand associations allow the information to be processed and organized in tourists buying decisions (Kwun and Oh, 2007, s.82-83). Tourists make their decisions to purchase decide with their feelings and emotions. In other words, tourists imagine an accommodations facility with their feelings and emotions (Sadeghi and Tabrizi, 2011: 698).

Brand associations inspire positive emotions and help to move these feelings to the brand (Erisen, 2010:25). For example, a lodging facility can form an association to the brand by using celebrities in advertisement campaign.

According to Kotler (2011:92), a brand association is everything that connects customers with brand. It includes everything related with accommodation facility such as visuals, features, usage patterns, brand personality and logos.

As a result, it is necessary to have positive brand association for consumer-based brand equity. Brand association helps for creating high brand equity in the minds of tourists with the support of attributes, benefits and the brand identity of the accommodation facility (Ercis et al., 2013:28). 


\subsection{Brand Loyalty}

Brand loyalty is the tendency to prefer a certain product or firm (Unal et al., 2006:1). Brand loyalty is a preference to choose the same accommodation business despite all marketing activities of competing accommodation facilities (Chaudhuri and Holbrook, 2001: 82), a positive feeling about this accommodation and an intention to prefer this lodging facility come back (Yilmaz and Ercis, 2012:32). Brand loyalty can be defined as the power of consumer confidence to brand (Uztug, 2003: 33; Doganli, 2006: 57; Selvi ve Temeloglu, 2008: 96).

Thiele and Bennett (2001: 26) defined brand loyalty as a function of psychological processes. Therefore, consumer's brand loyalty consists of two dimensions as behavioral loyalty and attitudinal loyalty and combination of these two loyalty dimensions reveal the real brand loyalty (Toksari, 2010:92). Oliver (1997:392) identify brand loyalty as a commitment that buying or using a preferred product or service in the future, despite the fact that situational influences and marketing efforts make a behavior change. Behavioral brand loyalty helps to continue to prefer a resort by tourists in the coming years.

Behavioral loyalty is criticized to be insufficient to explain the underlying reasons under repeating purchase behavior (Akyildiz, 2010:934). Some customers may prefer an accommodation that is the cheapest among similar category accommodations. These customers must be disconnected from customers who prefer an accommodation facility to others in accordance with the purchasing behavior (Devrani, 2009:408).

Behavioral brand loyalty can not only explain the acceptability of the brand, but also explain the customer's brand devotions (Ozkiris, 2010:32). Attitudinal brand loyalty approaches have been developed in order to eliminate the deficiency (Akyildiz, 2010:935). Attitudinal brand loyalty is the tendency of tourist loyalty to an accommodation facility. This is expressed by acceptance of the first choice of the facility (Taskin ve Akat, 2012: 135-136). Wilkie (1994:382) defined brand loyalty as consumers' positive attitudes towards a particular brand and a continuous buying behavior. Behavioral approach based on the definition of brand loyalty emphasizes consumer purchasing preferences resulting in a real commitment. Meanwhile, the attitudinal perspective emphasizes consumer demand related to the brand (Taskin ve Akat, 2012: 135-136).

Brand loyalty is important for preferring to an accommodation facility, but it is also necessary in terms of setting up the emotional commitment of tourists. Repeated purchases without emotional commitment are often referred as fake brand loyalty (Yaprakli and Can, 2009:268). Creating brand loyalty is one of the more preferred marketing strategies for accommodations. Because marketing costs to retain existing customers is less than marketing costs in order to obtain new customers (Wood, 2004:9). Loyal people can also influence in a positive way about branded accommodations. This helps to win new customers to branded accommodation (Yaprakli and Can, 2009:268).

Perceptions of customers who stay at a hotel are important for branding. In the study, a field survey was conducted to test the research hypothesis in a branded hotel operating at the city centre in Bursa.

\section{Methodology}

The research population is the customers who stay at a widely recognized hotel in Bursa. Data were collected by means of questionnaires. Survey was conducted to 276 customers who stay at the hotel and agreed to participate in questionnaires between July-August-September 2014. In this survey, we have tried to reach more participants. Limited time and unwillingness of customers to participate in research caused a decrease in sample size.

In the study, data collection techniques were utilized as a means of questionnaires. The survey consists of two parts. In the first part, there are questions about participants' overall judgments related to hotel and customers' demographic characteristics. In the second part, a scale consisting of 24 propositions is located in order to determine the impact of the brand dimensions on the brand equity. Propositions on the scale were formed by examining other studies in the literature (Aaker, 1996; Yoo and Donthu, 2000; Berry, 2000; Keller, 2001; Doganli, 2006; Pekyaman, 2008; Ipar, 2010; Toksari and Inal, 2011; Yilmaz and Ercis, 2012; Kocaman and Gungor, 2012).

The research data was analyzed with the help of a statistical software package SPSS for Windows. Descriptive statistics were used in order to determine the demographic characteristics of the participants. The percentage distribution, mean and standard deviation values have been utilized in order to interpret the level of participation of participants. Cronbach's alpha coefficients were calculated to test the reliability of the scale. For construct validity, factor analysis was conducted. Finally; the correlation analysis was performed to test the relationship between dimensions.

All data, with the exception of the demographic variables and information on brand equity and dimensions of brand equity, were collected using a 5-point Likert scale where $1=$ strongly disagree and $5=$ strongly agree.

\section{Research Findings}

Participants' demographic characteristics can be summarized as follows. $45,6 \%$ of participants is male and 54, $4 \%$ female. Participants' age is classified five categories. 32, $7 \%$ is under 30 years old. 20, 3\% is between 31 and 40 years old. $22,2 \%: 41-50 ; 15,4 \%: 51-60$ and $9,4 \%$ is over 61 years old. Professional distribution of the participants is as follows; unemployed:1,8\%, pensioners: $10,3 \%$, civil servants:10,0\%, self-employed:19,2\%, businessman:15,9\%, workers:3,0\%, executive: $9,6 \%$, housewife: $10,0 \%$, students: $14 \%$, farmers: $3 \%$ and others:3,3\%. Distribution of educational level of the participants; elementary: 10, 4\%, secondary: $8,5 \%$, high school: $21,9 \%$, undergraduate: $25,9 \%$, graduate: $22,6 \%$, 
postgraduate/ $\mathrm{PhD}: 10,7 \%$. The distribution of participants by level of personal income; under 1001: 17,2\%, 1001-2000: $15,0 \%, \quad 2001-3000: 16,1 \%, \quad 3001-4000: 11,4 \%$, 40015000: $10,3 \%$, over $5000: 18,7 \%$ and no income $11,3 \%$. The distribution of participants by level of family income; under 1001: $0,4 \%$, 1001-2000: 8,5\%, 2001-3000: 22,2\%, 3001-4000: $20,4 \%, \quad 4001-5000: 14,4 \%$ and over 5000: $34,1 \%$.

Table 1. Communication Tools That Affecting Hotel Preferences

\begin{tabular}{lll}
\hline Communication Tools & Yes $(\boldsymbol{\%})$ & No $(\boldsymbol{\%})$ \\
\hline Advice of friends and Relatives & 26,1 & 73,9 \\
Internet & 35,1 & 64,9 \\
Travel Agencies & 14,1 & 85,9 \\
Print Media & 6,2 & 93,8 \\
Oral and Visual Media & 12 & 88 \\
\hline
\end{tabular}

Table 1 shows that internet and friends' advice are the most effective communication tools for hotel choice. Travel agencies are the third and media is the lowest effective tool.

Table 2. The Reasons for Choosing the Hotel

\begin{tabular}{lll}
\hline Reasons & Yes $(\boldsymbol{\%})$ & No $(\boldsymbol{\%})$ \\
\hline Price suitability & 23,2 & 76,8 \\
Service diversity and quality & 45,2 & 54,8 \\
Staff approach & 7,4 & 92,6 \\
Variety of social activity & 14,7 & 85,3 \\
Ease of transportation & 17,6 & 82,4 \\
Food and beverage service quality & 11,1 & 88,9 \\
\hline
\end{tabular}

According to participants, service quality and diversity is the most effective reason for choosing this hotel. Price suitability, ease of transportation and variety of social activity follows it.

Table 3. The First Word Comes to Mind When Customers Hear the Hotel's Name

\begin{tabular}{lll}
\hline First Word & Yes $(\boldsymbol{\%})$ & No $(\%)$ \\
Business / convention & 16,7 & 83,3 \\
Entertainment/social activities & 31,3 & 68,7 \\
Economic prices & 10,2 & 89,8 \\
Safety & 4,7 & 95,3 \\
Service quality & 30,2 & 69,8 \\
Foods & 11,6 & 88,4 \\
Wedding / invitation & 11,6 & 88,4 \\
\hline
\end{tabular}

One of the main indicators of strong brand is the first word that comes to customers' mind. Table 3 shows that "entertainment/social activities" and "service quality" have the high degree among items (31, 3\% and 30, 2\%). Business/convention follows it with 16, 7\%; foods and weddings are $11,6 \%$. Economic prices are the $10,2 \%$. However, none of the items has $50 \%$ for the first word. In other word, none of the items is dominant for creating brand and variety of services influence the hotel brand equity.

Table 4. Wishes and Desires to Come Back to the Hotel

\begin{tabular}{lll}
\hline Desire To Come Back & Yes (\%) & No (\%) \\
\hline TOTAL & 88,5 & 11,5 \\
\hline
\end{tabular}

A satisfied customer is best way of being famous and creating brand. Table 4 shows that this hotel has high customers' satisfaction. A desire of staying at this hotel in the future is $88,5 \%$ of total customers, is an indicator for this assumption. In addition, $87,5 \%$ of total customers recommend this hotel to friends and relatives.

Table 5. Recommending the Hotel to Friends and Relatives

\begin{tabular}{lll}
\hline Recommends & Yes $(\%)$ & No $(\%)$ \\
\hline TOTAL & 87,5 & 12,5 \\
\hline
\end{tabular}

Table 6. The Scores Awarded to the Hotel Comparing With Others

\begin{tabular}{ll}
\hline Awarded (10 is the max) & Score \\
\hline TOTAL & 7,44 \\
\hline
\end{tabular}

In order to identify customers' perception about hotel, we applied a comparing score in our study. As a result, the participants awarded the hotel with 7, 44 of 10 points as seen table 6.

\subsection{Research Reliability}

Cronbach's Alpha test was used for the evaluation of the reliability of the scales in the study.

Table 7. Reliability Statistics

\begin{tabular}{lll}
\hline Scales & Cronbach's Alpha & N of Items \\
\hline Brand Awareness &, 84 & 4 \\
Brand Associations &, 90 & 8 \\
Perceived Quality &, 89 & 3 \\
Brand Loyalty &, 90 & 5 \\
Overall Brand Value &, 82 & 4 \\
Alfa $(\alpha)$ for All Scales &, 96 & 24 \\
\hline
\end{tabular}

All scales reliability coefficient was calculated as, 96. This value is quite high for internal consistency of the scale. Accordingly, it can be said that the scale is a reliable data collection tool.

\subsection{Research Validity}

Factor analysis was applied in order to examine the construct validity of the scale used in this study. Firstly, factor analysis was implemented for scale (in other words, the data set for factor analysis whether it is appropriate), to test the Kaiser-Meyer-Olkin (KMO) and sphericity (Bartlett's test) degrees were analyzed. Greater KMO value than 0.5 show convenience for factor analysis of data sets (Kalayci, 2006: 327).

As shown in the table 8, KMO 0.94 and $X^{2}: 5,552$, df: 276 and $\mathrm{p}<, 000$. These values are suitable for factor analysis of data set (, 94>, 500), respectively. Research data shows that the interests of the significant factors or variables 5,552 have been identified as the degree of sphericity. Obtained these values were statistically significant at the 0.000 level. In other words, there are high correlations between variables and the data set is suitable for factor analysis (Kalayci, 2006: 327).

After determining eligibility of KMO and Bartlett's test results, factor analysis was applied to the 24 propositions. In determining the appropriate number of factors in the 
selection of value which is greater than 1 is considered.

Table 8. KMO and Bartlett's Test

\begin{tabular}{lll}
\hline Scales & KMO Value & Result of Bartlett's Test \\
\hline Brand Awareness &, 70 & $\mathrm{X}^{2}: 592,787, \mathrm{df:} 6$ and $\mathrm{p}<, 000$ \\
Brand Associations &, 89 & $\mathrm{X}^{2}: 1,426, \mathrm{df}: 28$ and $\mathrm{p}<, 000$ \\
Perceived Quality &, 75 & $\mathrm{X}^{2}: 451,466, \mathrm{df}: 3$ and $\mathrm{p}<, 000$ \\
Brand Loyalty &, 86 & $\mathrm{X}^{2}: 862,406, \mathrm{df}: 10$ and \\
Overall Brand Value &, 67 & $\mathrm{p}<, 000$ \\
KMO and BT for All &, 94 & $\mathrm{X}^{2}: 511,342, \mathrm{df}: 6$ and $\mathrm{p}<, 000$ \\
Scales & $\mathrm{X}^{2}: 5,552, \mathrm{df}: 276$ and $\mathrm{p}<, 000$ \\
\hline
\end{tabular}

As a result of factor analysis, 3 factors were obtained which values greater than 1 . These 3 factors explain 71, 7\% of the total variance which was observed. But the 4 items had the lowest loading in the data set. Therefore, these 4 items deleted and analysis repeated again.

As a result of factor analysis, higher variance ratio mean is the stronger factor structure of the scale. However, in the social science's analyze, it is considered sufficient in multifactor structure if explained variance is between $40 \%$ and $60 \%$. The results of factor analysis are summarized below.

Table 9. The Result of Factor Analysis

\begin{tabular}{|c|c|c|c|c|c|c|}
\hline \multicolumn{2}{|l|}{ Factors } & \multirow[t]{2}{*}{ Load } & \multirow{2}{*}{$\begin{array}{l}\text { Eigen values } \\
6,995 \\
\end{array}$} & \multirow{2}{*}{ \% of Var. } & \multirow{2}{*}{$\begin{array}{ll}\mathrm{X} \\
4,38 \\
\end{array}$} & \multirow{2}{*}{$(\alpha)$} \\
\hline Item No & I. Factor (13 Items) & & & & & \\
\hline 5 & Accommodation facilities is sufficient in this hotel (rooms, furniture, beds, bathroom, TV, etc.). & ,772 & & & & \\
\hline 6 & Supporting facilities is sufficient at this hotel (food and drink, social activities, sports, etc.). & ,803 & & & & \\
\hline 7 & $\begin{array}{l}\text { This hotel's physical facilities are sufficient (infrastructure, building, additional facilities, parks, } \\
\text { etc.). }\end{array}$ & 819 & & & & \\
\hline 8 & This hotel's service quality is high. & ,799 & & & & \\
\hline 9 & This hotel's cleanliness and hygiene standards are high. & ,660 & & & & \\
\hline 13 & Service quality provided at this hotel is higher than the service provided in similar facilities. & ,630 & & & & \\
\hline 14 & Enough attention is given to customer complaints at this hotel. & 659 & & & & \\
\hline 15 & All the services provided at this hotel meet my expectations. & ,724 & & & & \\
\hline 16 & This hotel is my first choice when I need a hotel in Bursa. & ,520 & & & & \\
\hline 17 & I will continue to come back to this hotel when I need a hotel in the future. & ,731 & & & & \\
\hline 18 & I would recommend this hotel to anyone. & ,775 & & & & \\
\hline 20 & I always choose this hotel when I compare it with other facilities. & ,532 & & & & \\
\hline \multirow[t]{2}{*}{21} & I prefer this hotel as long as it has similar characteristics with other hotels. & ,619 & & & & \\
\hline & II. Factor (4 Items) & & 3,813 & 19,0 & 3,66 & ,710 \\
\hline 1 & This hotel is a well-known hotel in Bursa. & ,838 & & & & \\
\hline 2 & This hotel comes first to my mind among hotels in Bursa. & 867 & & & & \\
\hline 11 & I could easily distinguish this hotel from competing hotels. & ,640 & & & & \\
\hline \multirow[t]{2}{*}{12} & The advertisements about this hotel (written and visual media) are remarkable enough. & ,588 & & & & \\
\hline & III. Factor (3 Items) & & 3,540 & 17,7 & 4,31 & ,732 \\
\hline 19 & I choose this hotel even though price rise. & ,830 & & & & \\
\hline 22 & I still choose this hotel even if the price of other hotels more appropriate. & ,874 & & & & \\
\hline \multirow[t]{2}{*}{23} & I still choose this hotel even though service quality of other hotels would be better. & ,866 & & & & \\
\hline & TOTAL & & & 71,7 & & \\
\hline
\end{tabular}

According to the table 9; three factors explaining 71, 7\% of the total variance. First factor explains $35,0 \%$ of the total variance with Eigen value 6,995. This factor consists of variables; "Accommodation adequacy of hotel: ,772", "sufficiency of additional services: ,803", " adequacy of the physical facilities: ,819", "service quality: ,799", "hygiene standards: ,660", providing higher service quality than competitors: 630", "sensitivity to customer complaints: ,659", "ability to meet expectations of services: ,724", "the degree of choosing this hotel: ,520", "intend to come back again to the hotel: ,731", "recommending the hotels to others: ,775", "choosing the hotel by comparing with others: ,532" and "preferring the hotel depending on its similar characteristics with others: ,619". It can be seen by examining this factor that 5 items related to the brand association (5th, 6th, 7th, 8th and 9th substances), 3 items related to the perceived quality (13th, 14 th and 15th), 4 items related to brand loyalty (16th, 17th, 18th and 20th substances) and 1 item related to overall brand (21st substance).

Second factor explains $19,0 \%$ of total scale with 3,813 Eigen value. In this factor, 2 items belong to brand awareness, and other 2 items belongs to brand association. Third factor explains $17,7 \%$ of the total scale with 3, 54 Eigen value. This factor consists with 2 items from overall brand and one item from brand loyalty. It can also be seen by analyzing factors' loadings that the brand associations is the most effective dimension in creating customer-based brand equity.

\subsection{Correlation Analysis}

In order to examine the relationships between variables of the sub-scales, Pearson's correlation coefficients were calculated. The correlation coefficient takes a value between -1 and 1 . Value closer to " 0 ", while pointing to the low correlation and high correlation value closer to " 1 ". The value that higher than 0,70 are interpreted as powerful, the value between 0.70 to 0.30 as medium and a value less than 0.30 as a poor relation (Demir, 2012: 72).

Considering the correlation coefficients in Table 10, all variables have positive relationship at level $\mathrm{p}<0.01$ significance. There is a relationship between brand equity and brand awareness at strong level $(\mathrm{r}=0.810, \mathrm{p}<0.01)$, the most strong level relationship between brand equity and 
brand associations $(\mathrm{r}=0.934, \mathrm{p}<0.01)$, strong level relationship between brand equity and perceived quality ( $\mathrm{r}=$ $0.887, \mathrm{p}<0.01$ ), the second most powerful relationship between brand equity and brand loyalty $(\mathrm{r}=0.926, \mathrm{p}<0.01)$, strong level relationship between brand equity and overall brand $(\mathrm{r}=0.880, \mathrm{p}<0.01)$. These findings show that brand association is the most effective dimension in explaining customer-based brand equity scale. Brand loyalty is the second effective dimension. Perceived quality is the third and overall brand follows it. Brand awareness is the less effective dimension in the brand equity.

There is also high correlation between dimensions of the brand equity. There is a relationship between brand associations and brand awareness at strong level $(r=0.716, p$ $<0.01$ ), the medium level relationship between perceived quality and brand awareness $(r=0.602, \mathrm{p}<0.01)$, the medium level relationship between brand loyalty and brand awareness $(r=0.680, p<0.01)$, the medium level relationship between overall brand and brand awareness $(r=0.586, p$ $<0.01)$.

There is also strong correlation between perceived quality and brand associations $(\mathrm{r}=0.829, \mathrm{p}<0.01)$, strong relationship between brand loyalty and brand associations ( $\mathrm{r}$ $=0.778, \mathrm{p}<0.01)$, strong relationship between overall brand and brand associations $(r=0.722, \mathrm{p}<0.01)$. Finally, there is a strong relationship between brand loyalty and perceived quality $(\mathrm{r}=0.782, \mathrm{p}<0.01)$, strong relationship between overall brand and perceived quality $(r=0.725, \mathrm{p}<0.01)$ and strong relationship between overall brand and brand loyalty $(\mathrm{r}=0.855, \mathrm{p}<0.01)$.

Table 10. Correlation Coefficients of Variables

\begin{tabular}{|c|c|c|c|c|c|c|c|}
\hline & & AW & $\mathbf{A S}$ & PQ & BL & OB & BE \\
\hline \multirow[t]{3}{*}{ AW } & Pearson Correlation & 1 &, $716^{* * *}$ &, $602^{* *}$ & $680^{* *}$ &, $586^{* *}$ &, $810^{* *}$ \\
\hline & Sig. (2-tailed) & &, 000 &, 000 &, 000 &, 000 &, 000 \\
\hline & $\mathrm{N}$ & 273 & 268 & 269 & 266 & 272 & 259 \\
\hline \multirow{2}{*}{ AS } & Sig. (2-tailed) &, 000 & &, 000 &, 000 &, 000 &, 000 \\
\hline & $\mathrm{N}$ & 268 & 270 & 266 & 263 & 269 & 259 \\
\hline \multirow[t]{2}{*}{ PQ } & Pearson Correlation &, $602^{* *}$ &, $829^{* * *}$ & 1 &, $782^{* *}$ &, $725^{* *}$ &, $887^{* *}$ \\
\hline & $\mathrm{N}$ & 269 & 266 & 271 & 266 & 270 & 259 \\
\hline \multirow[t]{3}{*}{$\mathrm{BL}$} & Pearson Correlation &, $680^{* *}$ &, $778^{* *}$ &, $782^{* *}$ & 1 & $855^{* *}$ &, $926^{* *}$ \\
\hline & Sig. (2-tailed) &, 000 &, 000 &, 000 & &, 000 &, 000 \\
\hline & $\mathrm{N}$ & 266 & 263 & 266 & 269 & 268 & 259 \\
\hline \multirow[t]{3}{*}{$\mathrm{OB}$} & Pearson Correlation &, $586^{* *}$ &, $722^{* *}$ &, $725^{* *}$ &, $855^{* *}$ & 1 &, $880^{* *}$ \\
\hline & Sig. (2-tailed) &, 000 &, 000 &, 000 &, 000 & &, 000 \\
\hline & $\mathrm{N}$ & 272 & 269 & 270 & 268 & 275 & 259 \\
\hline \multirow[t]{2}{*}{$\mathrm{BE}$} & Pearson Correlation &, $810^{* *}$ &, $934^{* *}$ &, $887^{* *}$ &, $926^{* *}$ &, $880^{* *}$ & 1 \\
\hline & $\mathrm{N}$ & 259 & 259 & 259 & 259 & 259 & 259 \\
\hline
\end{tabular}

**. Correlation is significant at the 0.01 level (2-tailed).

\section{Conclusion}

Brand awareness, brand associations, perceived quality and brand loyalty are the main dimensions of consumerbased brand equity as stated many researchers in the literature (Aaker, 1996; Keller, 2001; Berry and Saltman, 2007). In addition, intangibility and the absence of pre-tested possibility of hotel's services makes more important to create a brand in the hospitality industry as in the industrial market (Pekyaman, 2008:111; Selvi and Temeloglu, 2008:100; Yilmaz and Ercis, 2012:29). Brand is not only to be expressed as the name, logo or symbol, at the same time it covers company's entire value of the tangible and intangible (Toksari, 2010:1). According to Murphy (1990:25) it consists also from certain privileges. He emphasize that the brand can also be created without name, sign, symbol or logo. In the light of these discussions, we tried to test the effect of brand equity dimensions on brand equity in the hospitality industry.

Research findings show that internet is the most effective communication tools for choosing a hotel. Friends' advice follows it.
It is very important that determining the effect of hotel services on brand equity by using data about customer perception at facility level. Research findings show that sufficient physical facilities is the most effective item on customer perception with ,819 factor loading. Sufficient supporting facilities is the second $(, 803)$, service quality is the third (, 799), sufficient accommodation facilities is the fourth $(, 772)$. Hygiene standards $(, 660)$ and attention is given to customer complaints $(, 659)$ follow it. The reasons of choosing a hotel can also listed by severity as service quality and diversification, price suitability, ease of transportation, variety of social activity, food and beverage service quality, and staff approach.

One of the main indicators of strong brand is the first word that comes to customers' mind (Berry, 2000). According to research participants, entertainment/social activity is dominant for the first word association in the mind with $(31,3 \%)$, service quality follows it with $30,2 \%$, and business/convention is $16,7 \%$.

A satisfied customer is also best way of being famous and creating brand for a hotel. The hotel which investigated in the study, desire of staying at this hotel in the future is $88,5 \%$ of 
total customers. It shows quite high customers' satisfaction. In addition, $87,5 \%$ of total customers recommend this hotel to friends and relatives. In order to identify customers' perception about hotel, we also applied a comparing score in the study. As a result, the participants awarded the hotel with 7, 44 of 10 points.

The research findings also show that the most effective dimension in creating customer-based brand equity is the brand associations $(r=0.934, p<0.01)$, brand loyalty is the second $(r=0.926, p<0.01)$, perceived quality is the third $(r=$ $0.887, \mathrm{p}<0.01)$ and overall brand follows them $(\mathrm{r}=0.880, \mathrm{p}$ $<0.01)$. Brand awareness is the less favorite effective dimension $(r=0.810, \mathrm{p}<0.01)$.

The research has a number of limitations. Obtaining the data only from a hotel is the first limitation of the study. It is difficult to generalize the research findings for other hotels. We intended to provide data from other hotels, but it was abandoned in which the case there would be no homogeneity of the participants. This approach can be considered more realistic. Secondly, we especially targeted to determine the impact of hotel facilities and services on brand equity by customer's perception as well as the impact of each dimension on the brand equity. But, we could not find a reliable scale about the impact of the services offered on brand equity in the hospitality sector. As a result, the study failed to reach the targets set in this regard. However, first time, we applied six items in order to test the effect of hotel services and facilities on brand equity in the literature $\left(5^{\text {th }}\right.$, $6^{\text {th }}, 7^{\text {th }}, 8^{\text {th }}, 9^{\text {th }}$ and $14^{\text {th }}$ items). Despite these limitations, our study has a number of strengths including new findings about the effect of hotel services and facilities on brand equity via customer perception as well as the effect of dimensions on brand equity regarding the application in the hotel sector.

Future research should extend our analysis to other hotel's brand. Comparing data that obtained from different hotels would be more useful. Furthermore, the study only tested the effect of brand equity components on brand equity. Future research may benefit from looking at the effects of hotel services and facilities on brand equity.

\section{References}

[1] Aaker, D. A. (1990). "Brand extensions: the good, the bad and the ugly", Sloan Management Review, 31 (4), 47-56.

[2] Aaker, D. A. (1991). "Managing Brand Equity: Capitalizing on the Value of a Brand Name". New York: The Free Press Maxwell Macmillan International.

[3] Aaker, D. A. (1996). "Measuring Brand Equity Across Products and Markets", California Management Review, 38 (3), 102-120.

[4] Aaker, D. A. (2007). Marka Degeri Yonetimi. (Translator: Ender Orfanli). Istanbul: Medicat Kitaplari.

[5] Aaker, D. A. (2013). Güclü Markalar Yaratmak. (Trans.: Erdem Demir). Istanbul: Mediacat Kitaplari.

[6] Ailawadi, K. L., Lehmann, D. R. and Neslin, S. A.(2003).
"Revenue Premium as an Outcome Measure of Brand Equity", Journal of Marketing Research, 38 (3), 102-120.

[7] Aktepe, C. and Sahbaz, R. P. (2010). “Turkiye'nin En Buyuk Bes Havayolu Isletmesinin Marka Degeri Unsurlari Acisindan Incelenmesi ve Ankara Ili Uygulamasi”, Cumhuriyet University Journal of Economics and Administrative Sciences, $11(2), 69-90$.

[8] Akyildiz, M. (2010). "Ozguven Duygusu Marka Bagliligini Gercekten Arttirir mi?”, Ege Academic Review, 10(3), 933950.

[9] Aysen, E., Yayli, A. and Helvaci, E. (2012). "Universitelerin Marka Kisiligi Algisinin Belirlenmesi Uzerine Bir Arastirma", Journal of Business Research (Turk), 4 (4), 182-204.

[10] Berry, L. and Seltman, K. D. (2007). "Building a Strong Services Brand: Lessons From Mayo Clinic", Business Horizons, 50, 199-209.

[11] Cabar, M. (2010). "Marka Imajina Yonelik Algilarina Gore Hedef Tuketicilerin Gruplanmasi ve Hijyenik Ped Sektorune Yonelik Pilot Bir Arastirma”, (Unpublished Thesis), Istanbul: Istanbul University SBE Pazarlama ABD.

[12] Chaudhuri, A. and Holbrook, M. B. (2001). "The Chain of Effects from Brand Trust and Brand Affect to Brand Performance: The Role of Brand Loyalty", Journal of Marketing, 65(2), 81-96.

[13] Christopher, M. (1996). "From Brand Values to Customer Value”, Journal of Marketing Practice: Applied Marketing Science, 2 (1), 55-66.

[14] Christodoulides, G. and Chernatony, L. (2010) Consumerbased brand equity conceptualisation and measurement: a literature review. International Journal of Market Research, 52 (1). 43-66.

[15] Cako, S. and Cinar, C. (2012). "Turkiye'de Insaat Sektorunde Yuklenici Firmalarin Markalasma Kriterleri Uzerine Bir Calisma”, Megaron, 7 (1), 36-48.

[16] Demir, M. O. (2012). Sosyal Bilimlerde Istatistiksel Analiz: SPSS 20 Kullanim Kilavuzu. Ankara: Detay Yayincilik.

[17] Devrani T. K. (2009). "Marka Sadakati Onculleri: Calisan Kadinlarin Kozmetik Urun Tuketimi Uzerine Bir Calisma", Suleyman Demirel Universitesi IIBF Dergisi, 14 (3), 407-421.

[18] Doganli, B. (2006). "Turizmde Destinasyon Markalasmasi ve Antalya Ornegi”, (PhD Thesis), Isparta: Suleyman Demirel Universitesi SBE Isletme ABD.

[19] Ercis, A., Yaprakli, S., Can, P. and Yilmaz, M.K. (2013). "Kisisel Degerler ile Marka Degeri Arasindaki Iliskiler", Ataturk Universitesi Iktisadi ve Idari Bilimler Dergisi, 27 (2), 21-41.

[20] Erdil, S. and Basarir, O. (2009). "Marka Cagrisimlari ve Satin Alma Davranisi Uzerine Olan Etkisinin Olcumlenmesi", Marmara Universitesi I.I.B.F. Dergisi, 27 (2), 217-231.

[21] Erdil, T.S. and Uzun, Y. (2010). Marka Olmak. Istanbul: Beta Basim Yayim Dagitim A.S.

[22] Erisen, T. (2010). "Kentler Icin Kulturel Markalasma Sureci ve Sanliurfa Ornegi", (Unpublished), Ankara: Gazi Universitesi Egitim Bilimleri Enstitüsü Turizm Isletmeciligi ABD. 
[23] Ertugrul, S. M. and Demirkol, S. (2007). "Turistik Urun Talebinde Markalasma ve Onemi”, Sosyal Bilimler Dergisi, 2, 61-70.

[24] Gil, R. B., Andres, E.F. and Salinas, E.M. (2007). "Family as a Source of Consumer-Based Brand Equity", The Journal of Product and Brand Management, 16 (3), 188-199.

[25] Godin, S. (2013). Mor Inek. (Trans.: Levent Goktem). Istanbul: Mediacat Kitaplari.

[26] Gunes, Gul. (2011). Konaklama Sektorunde Cevre Dostu Yonetimin Onemi, KMU Journal of Social and Economic Research, 13 (20), 45-51.

[27] Turkish Patent Institute. (2013). "Marka Farkliligin Kaliteyle Bulusmasidir", available at: http://www.turkpatent.gov.tr (accessed 15 November 2013).

[28] Ilban, M. O. (2008). "Seyahat Acenta Yoneticilerinin Destinasyon Marka Imaji Algilari”. Ege Academic Review. 8(1), 121-152.

[29] Ipar, M. S. (2010). "Turizmde Destinasyon Markalasmasi ve Istanbul Uzerine Bir Uygulama”, (Unpublished Thesis), Balikesir: Balıkesir Universitesi SBE Turizm ve Otel Isletmeciligi ABD.

[30] Jones, C. and Bonevav, D. (2013). “An Evolved Definition of theTerm "Brand": Why Branding has a Branding Problem”,Journal of Brand Startegy, 2 (2), 112-120.

[31] Kakati, R. P. and Choudhury, S. (2013). "Measuring Customer-Based Brand Equity Through Brand Building Blocks for Durables", The IUP Journal of Brand Management, 10 (2), 24-40.

[32] Kamakura, W. A. and Russell, G. J. (1993). "Measuring Brand Value with Scanner Data", Intern Journal of Research Marketing, 10, 9-22.

[33] Karacan, D. (2006). "Musteri-Odakli Marka Denkligi ve Marka Denkligi Unsurlarına Yonelik Tuketici Tutumlarinin Olculmesi: Otel Isletmeleri Uzerine Bir Uygulama”, (Unpublished Thesis), Adana: Cukurova Universitesi Sosyal Bilimler Enstitusu.

[34] Keller, K.L. (2001). "Building Customer-Based Brand Equity: A Blue print for Creating Strong Brands" Marketing Management, 10 (2), 15-19.

[35] Keller, K. L. (1998). Strategic Brand Management: Building, Measuring and Managing Brand Equity. New Jersey: Prentice-Hall.

[36] Kocaman, S. and Gungor, I. (2012). "Destinasyonlarda Musteri Temelli Marka Degerinin Olculmesi ve Marka Degeri Boyutlarinin Genel Marka Degeri Uzerindeki Etkileri: Alanya Destinasyonu Ornegi", International Journal of Alanya Faculty of Busines, 4 (3), 143-161.

[37] Kotler, P. (2011). B2B Marka Yonetimi. Istanbul:Mediacat Kitaplari.

[38] Kwun, D.J.W. and Oh, H. (2007). "Consumers' evaluation of brandportfolios", International Journal of Hospitality Management, 26(1), 81-97.

[39] Lassar, W., Mittal B., Sharma, A. (1995). "Measuring Customer- Based Brand Equity", Journal of Consumer Marketing, 12 (4), 11-19.
[40] Marangoz, M. (2007). "Marka Degeri Algilamalarinin Marka Yayilmaya Etkileri”, Ege Academic Review, 7 (2), 459-483.

[41] Moisescu, O. (2005). The Concept of Brand Equity-A Comparative Approach, Munich Personal RePEc Archive, Paper No: 32013

[42] Murphy, J. (1990). "Assessing The Value of Brands", Long Range Planning, 23 (3), 23-31.

[43] Netemeyer, R. G., Krishnan, B., Pullig, C., Wang, G., Yagci, M., Dean, D., Ricks, J. And Wirth, F. (2004). "Developing and Validating Measures of Facets of Customer-Based Brand Equity", Journal of Business Research, 57, 209-224.

[44] Oliver, R. L. (1997). "Satisfaction: A Behavioral Perspective on the Consumer". New York: McGraw-Hill.

[45] Ozguven, N. (2010). "Marka Degeri: Global Markalarin Degerlendirilmesi", SOBIAD Organizasyon ve Yonetim Bilimleri Dergisi, 2 (1), 141-148.

[46] Ozkiris, B. (2010). "Tuketicinin Imaji ile Marka Imaji Arasindaki Uyumun Marka Sadakati Uzerindeki Etkileri”, (Unpublished Thesis), Gebze: Gebze Ileri Teknoloji Enstitüsü Sosyal Bilimler Enstitüsü.

[47] Ozkul, E. and Demirer, D. (2012). "Sehirlerin Turistik Markalasmasinda Kalkinma Ajanslarinin Rolu: Bolge Planlari Uzerine Bir Dokuman Incelemesi”, Journal of Business Research (Turk), 4 (4), 157-181.

[48] Park, C.S. and Srinivasan, V. (1994). "A survey-based method fo measuring and understanding brand equity and its extendibility”, Journal of Marketing Research, 31 (2), 271-288.

[49] Pekyaman, A. (2008). "Turistik Satin Alma Davranisinda Destinasyon Imajinin Rolu Afyonkarahisar Bolgesinde Bir Arastirma", (Unpublished Thesis), Afyon: Afyon Kocatepe Universitesi Sosyal Bilimler Enstitusu.

[50] Sadeghi, T. and Tabrizi, K.G. (2011). "The Correlation Between Feelings and Brand Perception on Purchase Intention", World Applied Sciences Journal, 12 (5), 697-705.

[51] Selvi, M. S. and Temeloglu, E. (2008). "Otel Isletmelerinde Markalasmanin Tuketici Satin Alma Davranisi Uzerindeki Etkilerini Belirlemeye Yonelik Bir Arastirma”, Ege Academic Review, 8 (1), 93-120.

[52] Shabbir, J. and Rehman, K. U. (2013). "Impact of Perceptual Dimensions and Behavioral Dimentions on Brand Equity in Pakistan", Information Management and Business Review, 5(7), 347-359.

[53] Taskin, C. and Akat, O. (2012). Marka ve Marka Stratejileri. Bursa: Alfa Akademi Basim Yayim Dagitim Ltd.Sti.

[54] Thiele, R.S. and Bennett, R. (2001). "A Brand for all seasons? A discussion of brand loyalty approaches and their applicability for different markets." Journal of Product and Brand Management, 10(1), 25-37.

[55] Toksari, M. (2010). "Tuketici Temelli Marka Degerinin Olcumu: Kayseri'de Otomobil Kullanicilari Uzerine Bir Uygulama", (Unpublished Thesis), Nigde: Nigde Universitesi SBE Isletme ABD.

[56] Toksari, M. and Inal, M. E. (2011). "Tuketici Temelli Marka Degerinin Olcumu: Kayseri'de Otomobil Kullanicilari Uzerine Bir Uygulama”, Cag Universitesi Sosyal Bilimler Dergisi, 8(2), 69-97. 
[57] Trimeche, O., Trimeche, M. and Wakabayashi, Y. (2012). "Destination Branding: Managing Uncertainties in the MENA Region-The Cases of Dubai and Tunisia", African Journal of Business and Economic Research, AJBER, 7 (1), 24-46.

[58] Uztug, F. (2003). Markan Kadar Konus. Istanbul: Mediacat Kitaplar.

[59] Unal, S., Can, P. and Deniz, A. (2006). "Marka Bagliligi ile Kisisel Degerler Arasindaki Iliskiler: Universite Ogrencilerinin Spor Ayakkabi ve Cikolata Markalari Tercihi Uzerine Bir Arastirma", Cumhuriyet University Journal of Economics and Administrative Sciencies, 10 (1), 1-18.

[60] Vazquez, R., Rio, A. B. and Iglesias, V. (2002). "Consumer Based Brand Equity: Development and Validation of a Measurement Instrument", Journal of Marketing Management, 18 (1/2), 27-48.

[61] Virvilatie, R. and Jucaityte, I. (2008). "Brand Valuation: Viewpoint of Customer and Company", Engineering Economics, 56 (1), 111-119.

[62] Wilkie, W. L. (1994). Consumer Behavior (Third Edition). New York: John Wiley\&Sons Inc.
[63] Wood, L. M. (2004). "Dimensions of Brand Purchasing Behaviour: Consumers in the 18-24 Age Group", Journal of Consumer Behaviour, 4 (1), 9-24.

[64] Yaprakli, S. and Can, P. (2009). "Pazarlama Faaliyetlerinin ve Ailenin Tuketici Temelli Marka Degeri Boyutlarina Etkisi", Iktisadi ve Idari Bilimler Dergisi, 23 (1), 265-290.

[65] Yavuz, M. C. (2007). "Uluslar arasi Destinasyon Markasi Olusturulmasinda Kimlik Gelistirme Sureci: Adana Ornegi", (Unpublished Thesis), Adana: Cukurova Universitesi SBE.

[66] Yener, D. (2013). "Marka Cagrisim Unsurlarinin Marka Kisiligi Uzerine Etkisi", Electronic Journal of Vocational Colleges, 89-103.

[67] Yilmaz, M. K. I. and Ercis, A. (2012). "Endustriyel Pazarlarda Kisisel ve Kisisel Olmayan Bilgi Kaynaklarinin Marka Degeri Uzerindeki Etkilerinin Incelenmesi", International Journal of Alanya Faculty of Busines, 4 (2), 27 44.

[68] Yoo, B., Donthu, N. and Lee, S. (2000). "An Examination of Selected Marketing Mix Elements and Brand Equity", Journal of the Academy of Marketing Science, 28 (2), 195-211. 